\title{
TYÖELÄMÄN KOULUTUKSEN LINJAUKSIA
}

Antti Kauppi: Aikuiskoulutuksen suunnittelun kehityslinjoja. Helsinki: Valtion painatuskeskus 1989.

Antti Kauppi on kirjoittanut tarpeellisen kirjan. Lähtökohta on hyvä: '’Tässä esityksessä olen lähtenyt siitä, että ei ole yhtä ainoaa oikeaa tapaa suunnitella koulutusta, joka voitaisiin oppikirjassa välittää. Pikemminkin suunnittelijan itsensä on luotava erilaisia toimintamalleja uusiin tilanteisiin, joita hän kohtaa päivittäin." Mitä kirja sitten tarjoaa? Mielestäni kirjoittajan oman - kuten hän alkupuheessa painottaakin —, ja osittain perustelemattomaksi jäävän käsityksen siitä, mitä aikuiskoulutuksessa on tapahtunut ja missä nyt ollaan. Tulevaisuuteen Kauppi ei isommin ota kantaa.

Kirja käsittelee aikuiskoulutuksen suunnittelun ja suunnittelumallien historiaa sekä niiden muutoksia. Tekijän mukaan se on suunnattu erityisesti työelämän aikuiskouluttajille. Luulen, että muilla alueilla työskenteleville kirja jää vieraammaksi, koska muita alueita ei pahemmin käsitellä.

Lähestymistapa on historiallinen kahdessakin mielessä: kronologisesti lähdetään liikkeelle vuosisadan vaihteesta ja päädytään tämän päivän haasteisiin ja ratkaisuyrityksiin. Toisaalta käsiteltyjä näkemyksiä tai oppisuuntia tarkastellaan myös niiden teoreettisten juonteiden ja taustailmiöiden kannalta. Yritys on hyvä ja antaa perspektiiviä, mutta se jää osittain kesken kirjan sekavan ja monipolvisen rakenteen vuoksi.

Periaatteessa rakenne on erittäin selvä. Kirjan alussa luodaan pohja ja tarkastelukehikko, jonka mukaan loppu etenee. Joka luvun alussa kehikko toistuu ja siihen on merkitty, missä mennään. Luvun alussa kuvataan esiteltävän suunnittelumallin taustoja, sitten sen soveltamista henkilöstökoulutukseen ja lopuksi käsi- tellään sen teoreettisia lähtökohtia. Eli Kauppi orientoi lukijansa oikeaoppisesti, mutta vähän hampaat irvessä. Irvistys johtuu kirjan monikerroksisuudesta ja siitä, etteivät asiat pysy omissa koloissaan, vaan niitä käsitellään monessa kohtaa. Se sinänsä on ymmärrettävää. Tästä taas seuraa Torta på torta -ilmiö, tunne siitä, että "'tästä jo puhuttiin ja nyt se tuli taas, mutta oliko tässä jotain eroa aikaisempaan tai kokonaan uutta?"

Ehkä syynä on ennen kaikkea se, että kirjan "orientaatioperusta" on hyvin ennakkojäsentäjätyyppinen. Eri asiat pyritään sijoittamaan omiin laatikoihinsa ja tarkastelemaan asioita laatikko kerrallaan. Ennakkojäsentäjä ei kuitenkaan anna lukijalle kehystä, joka sisältäisi eri mallien analyysikriteerit. Näin ollen koko historiallisesta analyysista tulee analyysin sijaan enemmän kronikkamainen kuvaus siitä, mitä oli ensin ja mitä sitten. Kun kriteereitä ei selkeästi ole, tulee monen yksityiskohdan osalta mieleen, että ei se minusta ihan noin ole.

Kauppi sanoo alussa arvostavansa esittelemiään lähestymistapoja omalla tavallaan, mutta ei kerro lähtökohtiaan. Luulen, että jos hän olisi kuvannut alussa selkeämmin omat analyysiperusteensa ja arviointikriteerinsä, niin edellä mainitulta sekavuudelta olisi vältytty. Ehkä tarkastelu on myös turhan moninkertainen ja lukijan kannalta hankala. Kaupin toivomus, että lukija kävisi läpi lukujen lopussa olevaa lähdekirjallisuutta asioiden selkiinnyttämiseksi, on kaunis ajatus, mutta toisaalta vähän pallon heittämistä lukijalle.

Kaikesta huolimatta pidän kirjasta. Vaikka asioita on jo pitkään käsitelty muuallakin, esimerkiksi VKK:n kouluttajakoulutuksessa, niin 
Kauppi pystyy tuomaan uutta ja tuorettakin näkökulmaa. Lopun kehittävän työntutkimuksen kritiikki on terävä ja paikallaan, ainakin omaan työhöni sain siitä ideoita ja ajattelun aihetta. Tosin jäin kaipaamaan omissa yksiköissä kukoistavan työnopastuksen ja sen nykyisten tausta-ajatusten käsittelyä. Eikä Kauppi tunne niitä vai eikö hän pitänyt niitä mainitsemisen arvoisina?

Kuten sanottu, Kauppi on tehnyt erittäin tarpeellisen kirjan. Kirja on hyödyllinen kaikil- le, varsinkin uraansa alkaville, mutta myös kokeneille kouluttajille. Pieneen sivumäärään on saatu mahtumaan paljon asiaa. Toivottavasti ensimmäinen painos on niin pieni, että se myydään pikaisesti loppuun ja tekijä jaksaa panna toisen painoksen uusiksi. Olisi sääli jättää näin hyvää alkua kesken.

\section{MATTI HERMUNEN}

